\title{
Mosaic cri-du-chat syndrome in a girl with a mild phenotype
}

\author{
Lilia Maria de Azevedo Moreira ${ }^{1}$, Acácia Fernandes Lacerda de Carvalho ${ }^{2}$ \\ Ana Lúcia Vieira de Freitas Borja ${ }^{3}$, Paula Sanders Pereira Pinto ${ }^{4}$, Adriana Silveira, \\ Lucy Magalhães de Freitas ${ }^{1}$, Maria de Lourdes Lima Falcão ${ }^{6}$ \\ ${ }^{1}$ Laboratory of Human Genetics and Mutagenesis, Biology Institute, Federal University of Bahia (UFBA) - Campus Universitário de \\ Ondina, Salvador, Bahia, Brazil \\ ${ }^{2}$ DNA- Laboratory of Medical Genetics and Molecular Biology, Salvador, Bahia, Brazil \\ ${ }^{3}$ Institute of Sciences of Health, Federal University of Bahia (UFBA), Salvador, Bahia, Brazil \\ ${ }^{4}$ Psychology Department, Salvador University (UNIFACS), Salvador, Bahia, Brazil \\ ${ }^{5}$ Otorhinolaryngology Department, Santo Antonio Hospital, Salvador, Bahia, Brazil \\ ${ }^{6}$ Ophthalmology Department, Medicine College, Federal University of Bahia (UFBA), Salvador, Bahia, Brazil
}

\begin{abstract}
We report on the clinical observation of a girl patient with few signs of cri-du-chat syndrome. The chromosomal analysis in lymphocyte culture showed 46,XX,del(5)(p15.3) in 38\% of cells. Psychological tests revealed motor, perceptive and visual-spatial problems, as well as immaturity and emotional dependence. The phoniatric evaluation showed poor vocabulary, difficulty with repeating words or numbers in sequence, and better receptive than expressive language. The spectrographic measurements showed disturbance of fundamental frequency $\left(\mathrm{F}_{0}\right)$ in vocal pronunciation. The anatomic findings of the laryngoscopic evaluation were normal, indicating that the voice and speech problems were functional disorders. The present case revealed moderate clinical signs and vocal disturbance associated with a low percentage of $5 \mathrm{p}$ - cells and the breakpoint at $5 \mathrm{p} 15.3$. The short terminal deletion with a possible loss of the critical region for cat-like cry and the presence of a normal cell line, explain the cry not so typical at birth (weak but not high-pitched), the intermediate values of $\mathrm{F}_{0}$, and the moderate mental retardation. This case is compared with other mosaic $5 \mathrm{p}$ - patients reported in the literature.
\end{abstract}

Keywords: CdCS, mosaic cri-du-chat syndrome, speech and learning disabilities.

\section{Introduction}

The cri-du-chat syndrome (CdCS), OMIM\# 123450, firstly described by Lejeune et al. (1963), is a partial aneusomy resulting from haploinsufficiency of the distal segment of the short arm of chromosome 5, with an incidence of 1 in 50000 live births, and 1 in 350 severely mentally retarded people. The characteristic manifestations of the syndrome include vocal peculiarities (with a typical, striking, catlike cry during the first year of life), frequently associated with poor differentiation of the anatomical structure of the larynx. Psychomotor retardation, severe mental retardation, failure to thrive, and craniofacial dysmorphisms, with a round face, hypertelorism, epicanthal folds, down-slanting palpebral fissures, strabismus, broad nasal bridge, and micrognathia being more evident in infancy. There are dermatoglyphic traits, such as an increased number of whorls and arches, and a low frequency of ulnar loops; elevated t-triradius; and transverse flexion creases on the palm (Niebuhr 1978a).

The patients show a high variability in their developmental achievement, and the presence of a $\operatorname{del}(5 p)$ is not necessarily associated with a severe phenotype. Overhauser et al. (1994) and Gersh et al. (1995) distinguish 2 cri-du-chat critical regions (CdCCR): one for dysmorphism and mental retardation in $5 \mathrm{p} 15.2$, and one for the catlike cry in $5 \mathrm{p} 15.3$.

In a large series of CdCS patients, Mainardi et al. (2006) observed a great variability of deletions, with breakpoints ranging from $5 \mathrm{p} 15.2$ to 
$5 \mathrm{p} 11$, and confirmed the high percentage of terminal deletions $(81.8 \%)$. The previous review of 331 cases, reported by Niebuhr (1978a), estimated that about $80 \%$ of the cases resulted from de novo deletions, $12 \%$ were derived from a familial rearrangement, and a minority of cases involved other rare cytogenetic abnormalities. The occurrence of mosaicism is a very rare finding, with frequency estimated at about $3 \%$ of the CdCS patients. There are also cases of $\operatorname{del}(5 \mathrm{p})$ with deleted region pter-p15 to $\mathrm{p} 13$ in combination with duplication or deletion of another autosomal segment, with an abnormal but not typical CdCS phenotype (Schinzel 2001).

Here, a new case of the mosaic CdCS is described in a girl with relatively mild phenotypic manifestations, but cognitive and speech difficulties and other CdCS mosaic patients are reviewed.

\section{Patient and methods}

The proband is a 10-yea-old girl (Figure 1A). She was born at full term from healthy, nonconsanguineous parents, the mother being 31 and the father 26 years old at that time. The pregnancy was normal, and vaginal delivery took place without medical assistance. Her birthweight was $2600 \mathrm{~g}$ ( $3 \mathrm{rd}$ centile), length $45 \mathrm{~cm}$ ( 15 th centile), and head circumference $33 \mathrm{~cm}$ (10th centile). She cried weakly and had a round face, slight retrognathia and low-set ears. Psychomotor development was delayed; she walked at 2 years, spoke her first words at 18 months. At the age of 3 years, a heart defect (VSD) was diagnosed and surgically repaired. She presented with a failure to thrive, hypotonia, and minor facial dysmorphisms. Dermatoglyphics were considered to be normal: without distal t-triradius and no thenar or hyphothenar patterns on either of her hands; fingertips: $\mathrm{L}^{\mathrm{U}}$,twin-pocket $\mathrm{L}, \mathrm{L}^{\mathrm{U}}, \mathrm{L}^{\mathrm{U}}, \mathrm{L}^{\mathrm{U}}$ on the left hand; $\mathrm{L}^{\mathrm{U}}, \mathrm{L}^{\mathrm{U}}, \mathrm{A}, \mathrm{L}^{\mathrm{U}}, \mathrm{L}^{\mathrm{U}}$ on the right hand?; absence of transversal creases.

She had a convergent squint; hypotropic right eye; amblyopia, and hypermetropia. At present she shows delayed speech, has learning difficulties, and attends a special school for children with mild or moderate learning disabilities.

\section{Psychological development and personality traits}

Psychological tests were carried out to evaluate her social and cognitive performance, and showed a delay in fine motor development. Impaired men- tal development was revealed by difficulty related to perceptual analyses, communication and motor skills. Tests like the RAVEN, BENDER, CAT, HTP-F Progressive Scale and Piagetian Tests (Angelini et al. 1999; Clawson 1992; Bellak and Bellak 2000; Weis 1997; Kolck 1968; Hammer 1991) were performed. The first 3 tests were not in the least understood by the child, and the HTP Graphisms show a graphic quality equivalent to that of a child aged 2-3 years, with fragment figures and many circles. Motor, perceptive and visuospatial problems were also shown to be present.

In the Piagetian Tests, the patient demonstrated thinking that was still irreversible and centralized, with focus on only one dimension of a certain stimulus. However, in other, less elaborate games (like memory games), the patient showed that in spite of the difficulty, she was able to understand the rules, and tried not to break them. Furthermore, a moderate attention deficit was observed, with difficulty in speech, a weak vocal timbre, and frequently one did not understand what she said. Whenever she was asked to repeat what she had said, the child sometimes evaded speaking and tried to translate the words into gestures, without much patience. However, it was noted that the patient was able to carry on a dialogue and answer formulated questions, in spite of all the answers not being coherent with the questions she was asked. In addition to this, the patient demonstrated great difficulty with symbolic constructions, and was not apt to elaborate stories and representations, such as those demanded by the CAT test. She also demonstrated immaturity and emotional dependence, with an infantile concept of the world, and feelings of inadequacy with regard to the environment.

\section{Phoniatric evaluation}

The acoustic analysis was carried out through the CTS info VoxMetria program in a soundproof room, and digitalized on an ADM Athlon 2.0 computer with a 32-bit sound card with line-in input. A JWL unidirectional dynamic microphone, SM-24 model, was used at a distance of $10 \mathrm{~cm}$ from the patient's mouth at a 45-degree angle. For the fundamental frequency $\left(\mathrm{F}_{0}\right)$ analysis and its ranges of disturbance, the patient was asked to pronounce the vowel "E", and for the analysis of the vocal quality, she counted numbers. For vocal quality, an attempt was made to collect samples of chaining speech, but as the patient had a poor vocabulary, she used gestures to complement speech, 


\section{A}
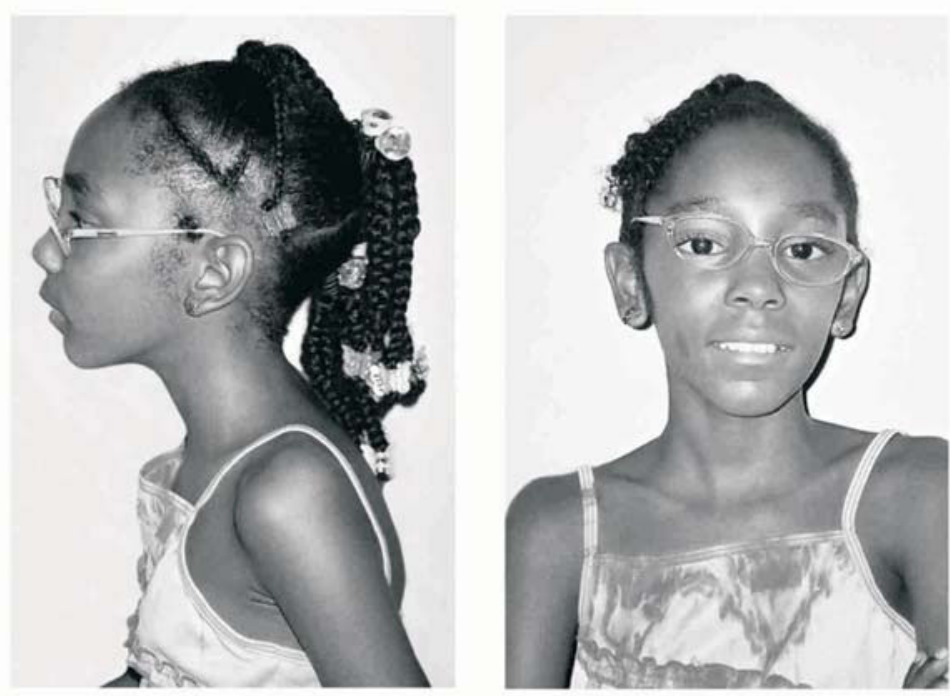

B
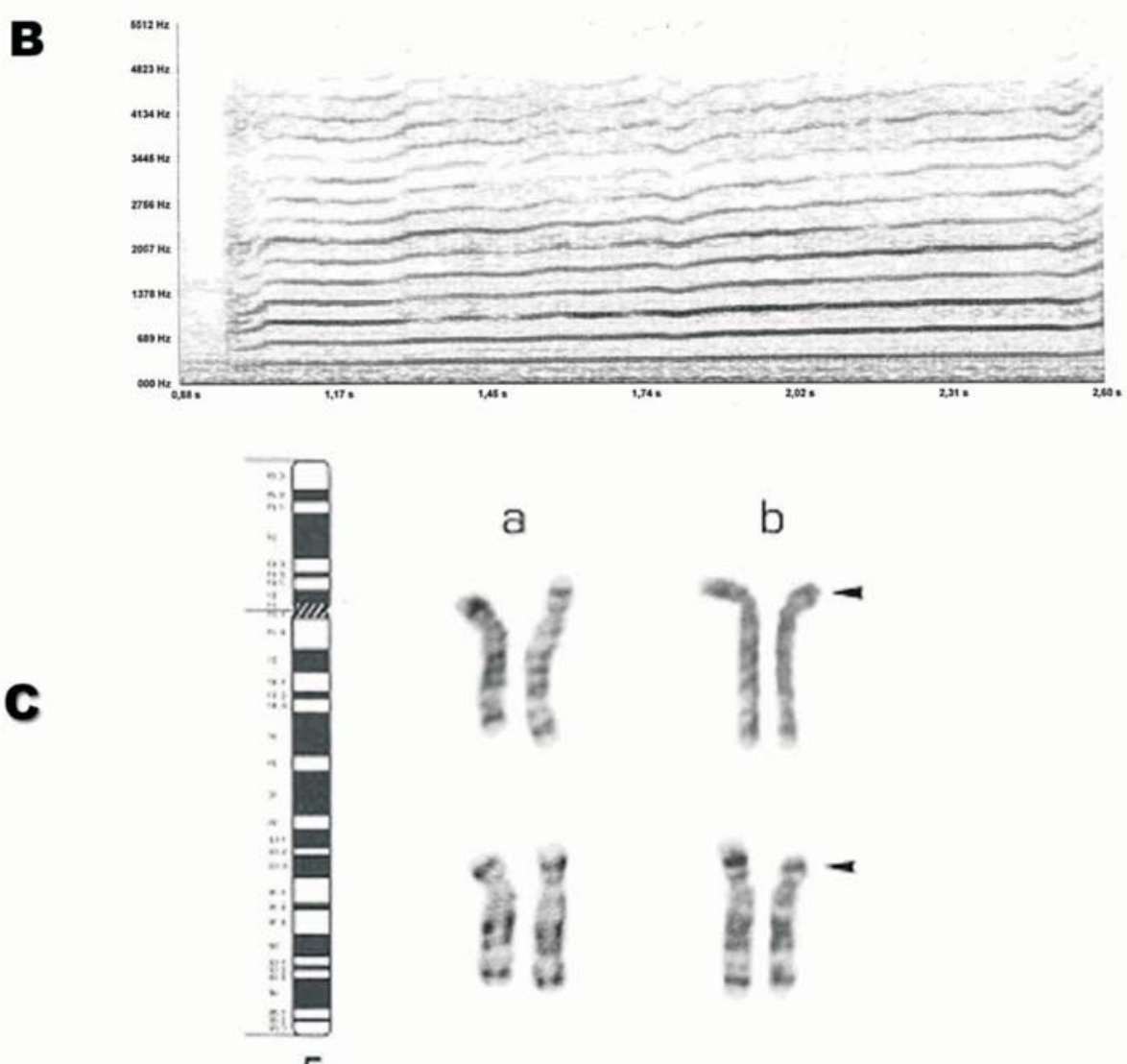

a

b
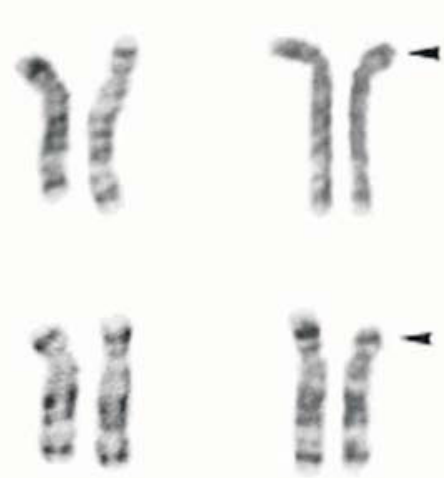

5

Figure 1. A. Frontal and lateral view of the girl at the age of 10 years. B. Sonogram of the patient showing high values of fundamental frequency $\left(\mathrm{F}_{0}\right)$ and slightly irregular tracing. C. Scheme of chromosome 5 (ISCN 2005) and partial karyotype of normal (a) and 5p- cells (b).

showing difficulty with repeating words or numbers in sequence, and presented better receptive than expressive language.

The spectrographic analysis measurements showed the following $\mathrm{F}_{0}$ values: maximum $469.90 \mathrm{~Hz}$; mean $364.80 \mathrm{~Hz}$, and minimum $275.86 \mathrm{~Hz}$, similar as those observed in the mosaic patient reported by Romano et al. (1991).
The disturbance ranges (jitter and shimmer) showed many alterations when compared to their reference values (Figure 1B). From the spectrogram it may be noted that at vocal onset, there was a rough vocal, attack with noise and a stretch of a frequency interruption during the emission of a sustained vowel. The harmonic structure of the sample did not reveal important 
abnormalities. The vocalization findings are consistent with what is found with a hypotonic larynx.

\section{Laryngoscopic evaluation}

The laryngoscopic evaluation was made by means of a flexible $3.2 \mathrm{~mm}$ fiberscope, Pentax model, after topical vasoconstriction of the right nasal cavity. The patient was asked to emit consonant sounds and swallow in order to evaluate the velopharyngeal sphincter and emit a sustained "E" and "I" vowel for a better visualization of the vocal cords. A very good coaptation and a rhinopharyngeal occlusion were observed.

The larger view of the larynges allowed a symmetrical organ to be observed, with good mobility and the dimensions expected for the age. The arytenoids were shown to be symmetrical and to have good mobility. The anatomic findings observed in these exams are often found in nonsyndromic children at this age.

\section{Cytogenetics investigations}

The proband's chromosome analysis was performed on standard peripheral blood lymphocytes, followed by the GTG banding procedure (ISCN 2005) and detected chromosomal mosaic (Figure 1C). Karyotype: 46,XX,del(5)(p15.3)[38]/46,XX[62]. The parents' karyotype was normal.

\section{Discussion}

Mosaicism in the $5 \mathrm{p}$ - syndrome has been described in a few sets of patients. The most frequently reported cases presented a normal cell line and another one with a $5 p$ deletion and a milder phenotype. Perfumo et al. (2000) estimated a frequency of mosaicism in $3.75 \%$ of CdCS and reported 3 cases of de novo $5 \mathrm{p}$ anomalies involving 2 rearranged cell lines and attributing some of the additional clinical features and malformations to the partial $5 p$ trisomy.

The study of this patient in fact is interesting because the deletion is small and the breakpoint is at $5 \mathrm{p} 15.3$, the level with CdCS for mild or moderate psychomotor retardation. The present investigation corroborates the point of view of slighter clinical manifestations in CdCS mosaic patients. In Table 1, characteristic clinical features in mosaic cases are compared (Philip et al. 1970; Niebuhr 1978b; Romano et al. 1991; Zellweger 1991; Perfumo et al. 2000; Chen et al. 2004). The phenotype-karyotype correlation shows a milder than expected phenotype in the cases with only one chromosome aberration, including the present patient. The findings of this investigation support the association of the critical $5 p$ deletion (5p15.2 until 5p15.3) with the typical cry and facial anomalies, but moderate mental retardation (Kjaer and Niebuhr 1999).

Table 1. Cytogenetic and clinical findings of reported cases of mosaic CdCS

\begin{tabular}{|c|c|c|c|c|c|}
\hline \multirow[t]{2}{*}{ Reference } & \multirow[t]{2}{*}{ Age } & \multirow[t]{2}{*}{ Sex } & \multicolumn{2}{|c|}{ Abnormal cells: 5p-/others (\%) } & \multirow[t]{2}{*}{ Phenotype } \\
\hline & & & Blood & Fibroblasts & \\
\hline Zellweger & $6 w$ & $\mathrm{~F}$ & 44 & - & typical CdCS \\
\hline Philip et al & $33 y$ & $\mathrm{~F}$ & 7 & - & normal, mother of a boy and a CdCS fetus \\
\hline \multicolumn{6}{|l|}{ Niebuhr } \\
\hline Patient 24 & & & 0 & 15 & typical CdCS \\
\hline Patient 29 & & & 8 & 4,6 & normal phenotype \\
\hline Patient 32 & & & 58 & 65 & atypical phenotype \\
\hline Romano et al. & $16 y$ & M & 25 & 30 & $\begin{array}{l}\text { mild craniofacial CdCS features; heart defects (VSD); } \\
\text { normal dermatoglyphics; psychomotor and speech de- } \\
\text { lay }\end{array}$ \\
\hline \multicolumn{6}{|l|}{ Perfumo et al. } \\
\hline Patient 1 & $6 y$ & $\mathrm{~F}$ & $73(5 p-) / 27(\operatorname{dup} 5 p)$ & - & epicanthic fold and hypertelorism; severe speech delay \\
\hline Patient 2 & $5 y$ & $\mathrm{~F}$ & $76(5 p-) / 24(\operatorname{dup} 5 p)$ & - & $\begin{array}{l}\text { recurrent bronchial and pulmonary infections; cranio } \\
\text { facial CdCS signs. high voice }\end{array}$ \\
\hline Patient 3 & $12 \mathrm{y}$ & $\mathrm{F}$ & $\begin{array}{l}78 \text { del (5pter-p13)/ } \\
22 \text { del (5pter-p14.3) }\end{array}$ & - & $\begin{array}{l}\text { classical CdCS phenotype, severe mental retardation, } \\
\text { hyperactive behavior }\end{array}$ \\
\hline Chen et al. & Fetus & $\mathrm{F}$ & - & 50(Aminiocytes) & $\begin{array}{l}\text { prenatal ultrasound: microcephaly, cerebellar } \\
\text { hypoplasia at } 21 \text { weeks Postnatal findings: } \\
\text { microcephaly, a triangular face, hypertelorism, } \\
\text { epicanthic folds, down-slanting palpebral fissures, } \\
\text { low-set ears, and micrognathia. }\end{array}$ \\
\hline Present case & $10 \mathrm{y}$ & $\mathrm{F}$ & 38 & - & $\begin{array}{l}\text { moderat CdCS signs, but VSD; vocal and cognitive } \\
\text { disturbances }\end{array}$ \\
\hline
\end{tabular}


Niebuhr (1978a) observed that the pathogenesis of the abnormal cry is not clear. In typical $\mathrm{CdCS}$, varying degrees of laryngomalacia or a small larynx have been observed, but in contrast to these cases, an apparently normal larynx was also presented in other cases in the literature. In the present patient, the laryngoscopic evaluation did not show abnormalities and it was concluded that the speech alterations probably arise from a functional disorder of the voice and speech mechanism.

Romano et al. (1991) compared the spectrographic findings in normal, $\mathrm{CdCS}$ and mosaic patients (all of them 16 years old), and found differences in $\mathrm{F}_{0}$, with intermediate values in the mosaic case. The present report makes a contribution to this question and shows electroacoustic signs similar to the findings of Romano et al. (1991), especially when the difference in the patients' sex and age is considered. According to Behlau (2001), $F_{0}$ is affected by gender and age, with an average distribution of $80-250 \mathrm{~Hz}$ in young adults. Children presented values of over $250 \mathrm{~Hz}$, reaching $400 \mathrm{~Hz}$; in babies there is a wide range from 100 to $1200 \mathrm{~Hz}$. The lack of reports on phoniatric evaluations in $5 \mathrm{p}$ mosaicism does not yet allow one to draw a safe conclusion about these vocal aspects, but the spectrographic evaluation revealed varying degrees of harm to the voice, according to the percentage of $5 \mathrm{p}$ - cells involved, as suggested by Romano et al. (1991).

The cry is not so typical at birth (weak but not high-pitched) and the intermediate values of fundamental frequencies at the age of 10 , were considered all due to the normal cell line. It can be concluded that in spite of the loss of the CdCCR in a cell line, the presence of a normal cell line contributes to the mild phenotype. Like the CdCS syndrome cases reported by Cornish et al. (1997), the patient in the present study showed better receptive than expressive language, indicating the importance of developing nonverbal commands to improve patients' performance in dealing with the behavioral and learning problems encountered in these conditions.

Acknowledgments. We thank Mr. Iago Teles Dominguez Cabanelas, Miss Elenilda Nascimento Menezes, Miss Rafaella Nunes Mourăo and Mr. Regivaldo Costa Almeida for their technical assistance.

\section{REFERENCES}

Angelini AL, Alves ICB, Custódio EM, Duarte WF, Duarte JLM, 1999. Matrizes Progressivas Coloridas de Raven. Manual. Săo Paulo: Centro Editor de Testes e Pesquisas em Psicologia.
Bellak L, Bellak SS, 2000, Manual para o Suplemento do Teste de Percepçăo Infantil (CAT-A). Săo Paulo: Editora Livro Pleno.

Behlau M, 2001. Avaliaçăo acústica do sinal sonoro. In: Voz-O livro do especialista. Rio de Janeiro: Editora Revinter.

Chen C-P, Lee C-C, Chang T-Y, et al. 2004. Prenatal diagnosis of mosaic distal $5 p$ deletion and review of the literature. Prenatal Diagnosis 24: 50-57.

Clawson A, 1992. Bender infantil: Manual de diagnóstico clínico, 7th ed. Porto Alegre:Artes Médicas.

Cornish KM, Bramble D, Munir F, Pigram J, 1999. Cognitive functioning in children with typical cri du chat (5p-) syndrome. Developmental Medicine and Child Neurology 41: 263-266.

Gersh M, Goodart SA, Pasztor LM, et al. 1995. Evidence for a distinct region causing a cat-like cry in patients with $5 \mathrm{p}$ deletions. American Journal of Human Genetics 56: 1404-1410.

Hammer E, 1991. Aplicaçőes clínicas dos desenhos projetivos. Săo Paulo: Ed. Casa do Psicólogo.

Kolck OLV, 1968. Interpretaçăo psicológica de desenhos. Săo Paulo: Biblioteca Pioneira de Cięncias Sociais.

Kjaer I, Niebuhr E, 1999. Studies of the cranial base in 23 patients with Cri-du-Chat syndrome suggest a cranial developmental field involved in the condition. American Journal of Medical Genetics 82: 6-14.

Lejeune J, Lafourcade J, Berger R, et al. 1963. Trois cas de delétion partielle du bras court d'une chromosome 5. Comptes Rendues de l'Académie des Sciences 257: 3098-102.

Mainardi PC, Pastore G, Castronovo C, Godi M, Guala A, Tamiazzo S, et al. 2006. The natural history of Cri du Chat Syndrome. A report from the Italian Register, European Journal of Medical Genetics 49: 363-383.

Niebuhr E, 1978a. The cri du chat syndrome. Epidemiology, cytogenetics and clinical features. Human Genetics 44: 227-275.

Niebuhr E, 1978b. Cytologic observations in 35 individuals with 5 p- karyotype. Human Genetics 42 : $143-156$.

Overhauser J, Huang X, Gersh M, et al. 1994. Molecular and phenotypic mapping of the short arm of chromosome 5: sub localization of the critical region to cri du chat syndrome. Human Molecular Genetics 3: 247-252.

Perfumo C, Mainardi P, Cali A, et al. 2000. The first three mosaic cri du chat syndrome patients with two rearranged cell lines. Journal of Medical Genetics 37: 967-972.

Philip J, Brandt NJ, Friis-Hansen B, et al. 1970. A deleted $\mathrm{B}$ chromosome in a mosaic mother and her Cri du Chat progeny. Journal of Medical Genetics 7: 33-36.

Romano C, Ragusa RM, Scillato F, 1991. Phenotypic and phoniatric findings in mosaic cri du chat syndrome. American Journal of Medical Genetics 39: 391-393. 
Schinzel A, 2001. Catalogue of unbalanced chromosome aberrations in man, 2nd ed. Walter de Gruyter, Berlin; New York.

Shaffer LG, Tommerup N, ISCN 2005. In: Karger S, Basel, eds. An International System for Human Cytogenetic Nomenclature.
Zellweger H, 1966. Cri-du-Chat with mosaicism. Lancet $2: 57$.

Weis MLL, 1997. Provas do diagnóstico operatório. In: Psicopedagogia Clínica: uma visăo diagnostica dos problemas de aprendizagem escolar. 3rd. Rio de Janeiro: DP\&A. 